Arboriculture \& Urban Forestry 2015. 41(1): 41-48

\title{
A Comparison of Arborists' and Horticulturists' Preferences of Tsuga chinensis to T. canadensis in the Urban Landscape
}

\author{
Jason E.E. Dampier, Richard W. Harper, Lora Schwartzberg, and \\ R. Harvey Lemelin
}

\begin{abstract}
Recent research describing host resistance of hemlocks to the lethal, invasive insect hemlock woolly adelgid has suggested that Chinese hemlock (Tsuga chinensis) may be a suitable pest-resistant urban landscape replacement for eastern hemlock (T. canadensis). Presented here are the research findings of an in situ field questionnaire survey and participant observations. The study's objective was to collect and evaluate arborists' and other horticulturists' perceptions and purchase preferences between eastern and Chinese hemlock to assess whether Chinese hemlock has potential to be accepted as an alternative landscape replacement for eastern hemlock. Fifty-five participants visually inspected both hemlock specimens and responded to questions about which one they would prefer to purchase, what their preferences would be in light of potential insect resistance, and the likelihood of fewer insecticide applications being required. Multiple cross-tabulations indicated that there was no statistical association (Fisher's Exact Test, $P>0.05$ ) between participant background (i.e., arborists versus others) and questions related to general purchase preference, and purchase preference if a specimen exhibited natural pest resistance or required less pesticides. Over three-quarters of participants were more inclined to purchase the specimen that possessed resistance to a serious pest. These findings suggest that Chinese hemlock may potentially serve as a hemlock woolly adelgid-resistant alternative to eastern hemlock in the landscape.

Key Words. Adelges tsugae; Arborist; Chinese Hemlock; Eastern Hemlock; Hemlock Woolly Adelgid; Horticulturist; Invasive Species; Participant Perceptions; Survey; Tsuga canadensis; Tsuga chinensis.
\end{abstract}

Eastern North America has experienced a number of invasive pest introductions, which have had serious and lasting impacts relative to native forest tree species populations (Gandhi and Herms 2010). The ramifications associated with invasive pests, however, are not isolated to rural forested settings. Their impacts may also affect urban trees in community settings. Invasive pathogens, such as Dutch elm disease (Ophiostoma novo-ulmi Brasier) and chestnut blight [Cryphonectria parasitica (Murrill) Barr], have devastated trees in municipal parks, urban streets, and privately owned landscapes, necessitating their removal (Schlarbaum et al. 1998) and reducing urban tree canopy cover. Additionally, invasive insects, such as gypsy moth (Lymantria dispar Linnaeus) (Childs 2011), Asian longhorned beetle (Anoplophora glabripennis Motschulsky) (Haack et al. 2010), and emerald ash borer (Agrilus planipennis Fairmaire) (Poland and
McCullough 2006), have also been deleterious to native tree populations in the urban environment.

Hemlock woolly adelgid (Adelges tsugae Annand) (HWA) is a widely recognized pest of native easternhemlock [T.canadensis (L.) Carrière] trees (Figure 1a). The insect was originally introduced to the eastern United States from Asia in the early 1950s (Havill and Montgomery 2008). Free from natural predation and apparently adapted to the climate, HWA has presently infested 50\% of the T. canadensis range (Kok et al. 2013).

Where HWA infestation is present, the wellbeing and even survival of T. canadensis is contingent upon applications of contact (i.e., horticultural oils) and systemic insecticides (Raupp et al. 2008). These treatments are costly and their use may include negative risks associated with human and environmental health (Gilden et al. 2010). Furthermore, general public concern and nega- 


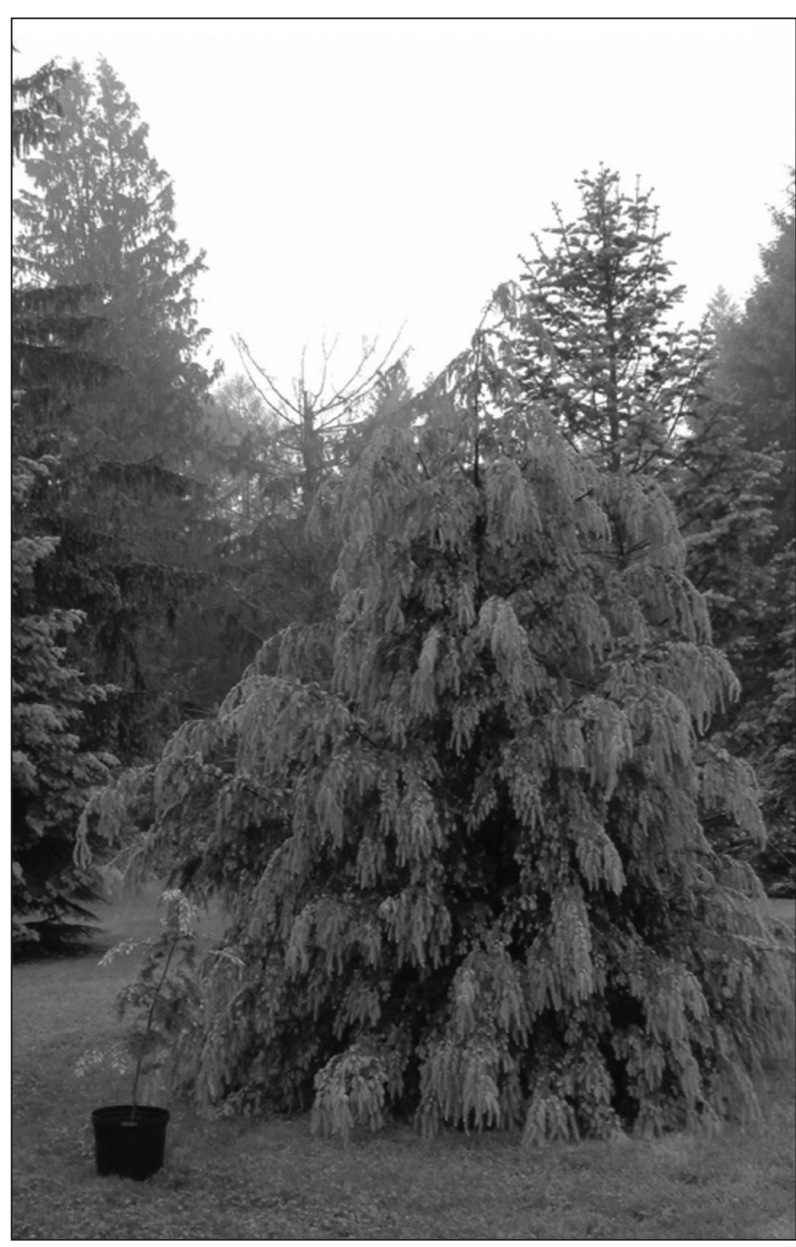

Figure 1a. Open-grown mature and immature samples used in this study (potted left of mature specimen). Pictured here: Chinese hemlock (Tsuga chinensis).

tive perceptions exist regarding the use of insecticides (Dunlap and Beus 1992; Peterson 2000). An alternative to long-term reliance on insecticide use may include a series of integrated approaches (Dreistadt et al. 1990) for HWA control, such as the use of beneficial biocontrols. These biocontrols include Laricobius nigrinus Fender, Sasajiscymnus tsugae Sasaji \& McClure, and Scymnus sinuanodulus Yu et Liu (Onken and Reardon 2011). Other strategies include the establishment of other, non-susceptible conifer species (i.e., Pinus spp. or Picea spp.) (Ward et al. 2004) and the use of HWA-resistant Tsuga ' $x$ ' hybrids. Each of these strategies has its limitations, however. Biocontrols may experience challenges related to supply viability, method of application, and/or overall efficacy related to HWA population reduction (Onken and Reardon 2011). Alternative conifer species may possess different autecological requirements and aesthetic features than T. canadensis (Dirr 2009). Furthermore, while it is worth noting that HWAresistant hybrid Tsuga ' $X$ ' spp. are currently in development (Olsen and Bentz 2010), they may not be commercially available for many years (M. Montgomery, USDA Forest Service, pers. comm.).

Ongoing market demand for $T$. canadensis is attributed to the tree's shade tolerance, its dense growth habit, attractive foliage, favorable response to shearing, and suitability both as a hedge and specimen tree (Godman and Lancaster 1990; Ingram 2002). Thus, arborists and other horticulturists are continually seeking innovative, cost-effective, and environmentally responsible ways to manage HWA. Therefore, replacing HWA-susceptible Tsuga spp. with an insect-resistant Tsuga sp. that features similar autecological requirements and aesthetic traits may be a viable alternative in the managed landscape (Ward et al. 2004).

A number of studies from the northeastern U.S. suggest that Chinese hemlock [Tsuga chinensis (Franch.) E. Pritz] (Figure 1b) can both acclimate to the region and demonstrate excellent resistance to HWA, making it a potentially well-suited replacement for $T$. canadensis (Del Tredici and Kitajima 2004; Bentz et al. 2006; Evans 2008; Hoover et al. 2009; Montgomery et al. 2009; Weston and Harper 2009; Joseph et al. 2011). Although participant perception research has been conducted in Asia investigating perceptions of T. chinensis' wood texture and color (Chen et al. 2009), this study is the first North American investigation to formally examine in situ participant field perceptions of its role as a potential HWA-resistant alternative. Arborists' and other horticulturists' perceptions of T. canadensis versus T. chinensis were collected and analyzed. If proven viable among these groups, T. chinensis may offer a lower-maintenance alternative to the visually similar, more pest-susceptible T. canadensis.

The specific objectives of this study were to 1) evaluate the extent to which arborists and other horticulturists could visually distinguish between $T$. chinensis and T. canadensis, and 2) determine to what extent participants may or may not prefer purchasing $T$. chinensis over $T$. canadensis, based on its inherent pest-resistance and the likelihood of fewer insecticide applications. 


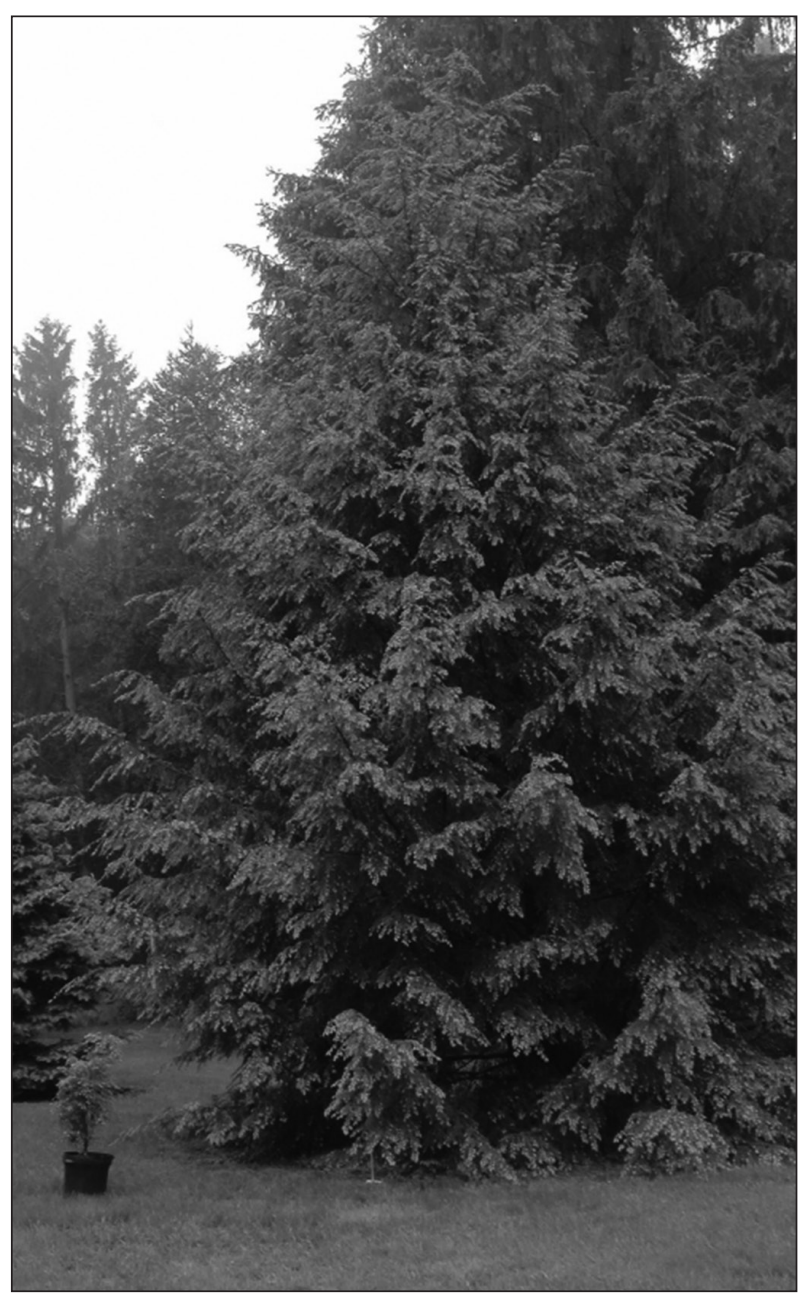

Figure 1b. Open-grown mature and immature samples used in this study (potted left of mature specimen). Pictured here: Eastern hemlock (Tsuga canadensis).

\section{MATERIALS AND METHODS}

The T. canadensis and T. chinensis specimens were located at Lasdon Park \& Arboretum $\left(41.2759^{\circ} \mathrm{N}, 73.7346^{\circ} \mathrm{W}\right)$, which is approximately 94 ha and is owned and operated by Westchester County's Department of Parks, Recreation, and Conservation in Katonah, New York, U.S. Both specimens used in the evaluation were open grown, in full sun, and located within a deer-fenced perimeter. The $T$. canadensis and T. chinensis both exhibited densely leafed, opengrown, excurrent branching habit and were 8.60 $\mathrm{m}$ and $4.88 \mathrm{~m}$ in height, respectively. Juvenile, potted T. canadensis and T. chinensis specimens were placed next to their mature counterpart to provide participants with a sample of what nursery stock may look like (see Figure 1). Both trees were free of HWA, although the T. canadensis had received routine insecticide treatments over the years, while the $T$. chinensis required none. A video presenting the specimens can be viewed online (www.urbanforestrytoday.org).

\section{Data Collection}

Early in the design stage, the research team decided that participant interactions in situ with actual Tsuga spp. specimens would provide more meaningful study results than using an ex situ approach, which would have employed mailout surveys with specimen photographs. Though potentially useful in increasing participant numbers, this strategy would have produced a potentially lower quality, less-robust evaluation of the specimens as participants would have been unable to use their various senses (e.g., touch, smell) and encounter the Tsuga spp. specimens first-hand.

A field survey instrument was developed and tested on April 19, 2013, which included a "dry run" completion of the survey by participants possessing a background in horticulture. Feedback from the field test was used to finalize the survey, which was administered to participants on May 29 and May 30, 2013. Survey questions included: i) Which specimen would you be more likely to purchase; ii) Would you agree or disagree that these two specimens are the same species; iii) Would you be more or less inclined to purchase one of these specimens if it were naturally-resistant to a serious pest problem; iv) Would you be more or less inclined to purchase one of these specimens if it required fewer insecticide applications? Survey questions were constructed using a five-step Likert scale (i.e., like very much, like, neutral/no opinion, dislike, and dislike very much). A "no opinion" option was included to allow responses from undecided participants (Raaijmakers et al. 2000).

Research survey participants were recruited based on the following sampling criteria:

i) They possessed specialized skills, such as the ability to identify trees, which are common to individuals who possess a pre-existing degree of knowledge pertaining to arboriculture/horticulture;

ii) They had specialized experiences, such as applying pesticides or implementing an Integrated Pest Management (IPM) program on landscapes, which are common to green industry professionals 
or paraprofessionals who may have maintained Tsuga spp. within the infestation range of HWA;

iii) They lived or worked within driving distance of the research site, for ease of travel and in-person participation.

These criteria were employed because the research team wanted to recruit participants with these "particular features" rather than participants without specialized knowledge from the general population (Ritchie et al. 2003). The team also anticipated that recruitment from the general population would have led to lower overall participation rates since the study required that participants attend in-person for approximately one hour. It was anticipated that only individuals interested in the topic would fully commit to the survey process and the required time. Furthermore, the research team anticipated increased engagement from participants that were already interested or experienced in the arboriculture or horticulture sector.

Participant recruitment was carried out through several e-mail notices that were sent via list-serves from Cornell University Cooperative Extension associations in the New York, U.S., counties near the study site, with emphasis on Westchester and Putnam Counties. In order to estimate the proportion of ISA Certified Arborists ${ }^{\circledast}$ who participated, cities, towns, villages, and hamlets within Westchester and Putnam Counties were searched within the International Society of Arboriculture (ISA) "Find a Tree Care Service" database (ISA 2014). This online tool is widely used by tree care customers when locating professional, qualified tree-care service providers in their communities; it may also provide a good estimate of how many certified arborists are in a given community or region.

Over the two-day period, participants in groups comprised of three to 12 individuals were lead to the T. canadensis and T. chinensis specimens hourly. Participants provided their background information and were categorized based on their response as either "arborist" $(\mathrm{n}=21,38 \%)$ or "other" $(\mathrm{n}=34$, $62 \%$ ), which included horticulturists, landscapers, foresters, nurserymen, and master-gardener volunteers. They were then asked to complete the survey, which took approximately 30 minutes. Participants were asked not to talk to each other while evaluating the specimens and completing the survey. Additionally, research team members joined the groups and took participant observation field notes. After the completed surveys were returned, participants were debriefed and provided with a short in-field training session that included a discussion contrasting and comparing the features of $T$. canadensis and T. chinensis.

Participant responses were then analyzed in PASW Version 18 (SPSS 2009). Cross-tabulations were established in order to conduct data summaries and to conduct Fischer's Exact Tests (Field 2009). Affirmative and negative responses were pooled to allow for a series of $2 \times 2$ cross-tabulations. For example, "strongly agree" and "agree" were pooled, as were "strongly disagree" and "disagree." Survey questions that were either left blank or indicated "no opinion" were disregarded in the data analysis. A total of 55 participants completed the survey, but since unanswered questions were not included in the cross-tabulations, participant counts ranged from 36 to 51 (unpublished).

\section{RESULTS AND DISCUSSION}

It was estimated that there are approximately 130 to 170 ISA Certified Arborists based in Putnam and Westchester Counties. Therefore, approximately $12 \%$ to $16 \%$ of arborists in these counties participated in this research. Furthermore, it is unlikely that all of the participants who selfidentified as certified were in fact certified with ISA. Although it is acknowledged that results cannot truly be inferred beyond the actual participants, their survey responses may be indicative of other local arborists (and horticulturists). Since unanswered questions were not included in the crosstabulations, some questions had less than a 55 participant response rate. Arborists' responses ranged in number from 15 to 19 and others' responses ranged in number from 26 to 33 (unpublished).

The multiple cross-tabulations presented in Table 1 , indicate that there was no statistical association (FET, $P>0.05$ ) between participant backgrounds (e.g., arborists' versus others') when compared to other responses. The lack of statistically significant associations suggest that participant background has no bearing on preferences relative to specimen partiality, the ability to tell the difference between specimens, or their purchase inclination based on natural pest-resistance, or fewer insecticide applications required (Table 1). Overall, participants 
were split regarding specimen purchase preference, with $49 \%$ of participants preferring $T$. chinensis while $51 \%$ of participants preferred T. canadensis (Table 1). Furthermore, about one quarter of the participants $(28 \%$, Table 1$)$ were unable to tell that the two specimens were different, suggesting that either specimen could be potentially interchangeable for a proportion of the individuals surveyed.

The majority of all participants (regardless of background) were more inclined to purchase one specimen over the other if it was resistant to a serious pest $(79 \%$, Table 1$)$, or if it required fewer insecticide applications ( $80 \%$, Table 1$)$. This suggests that even for those participants who could correctly discern that the two specimens were different, natural pest resistance and fewer insecticide applications would be a factor in purchase preference. Additional cross-tabulations elucidate this idea further. There was no statistical association (Table 2), (FET > 0.05) between the participants' ability to identify that the specimens were different versus their purchase preferences based on natural pest resistance or fewer insecticide applications. This suggests that regardless of their ability to correctly discern if the specimens were different, most participants preferred the specimen that possessed natural pest resistance $(80 \%$, Table 2$)$ or the specimen that required fewer insecticide applications (80\%, Table 2).

In addition to the survey data results, participant observations also indicated that $T$. chinensis is a potential landscape replacement for T. canadensis. Participants were curious about $T$. chinensis. Written

Table 1. Participant backgrounds, versus questions related to plant origin preference, purchase preference, and ability to detect specimen differences.

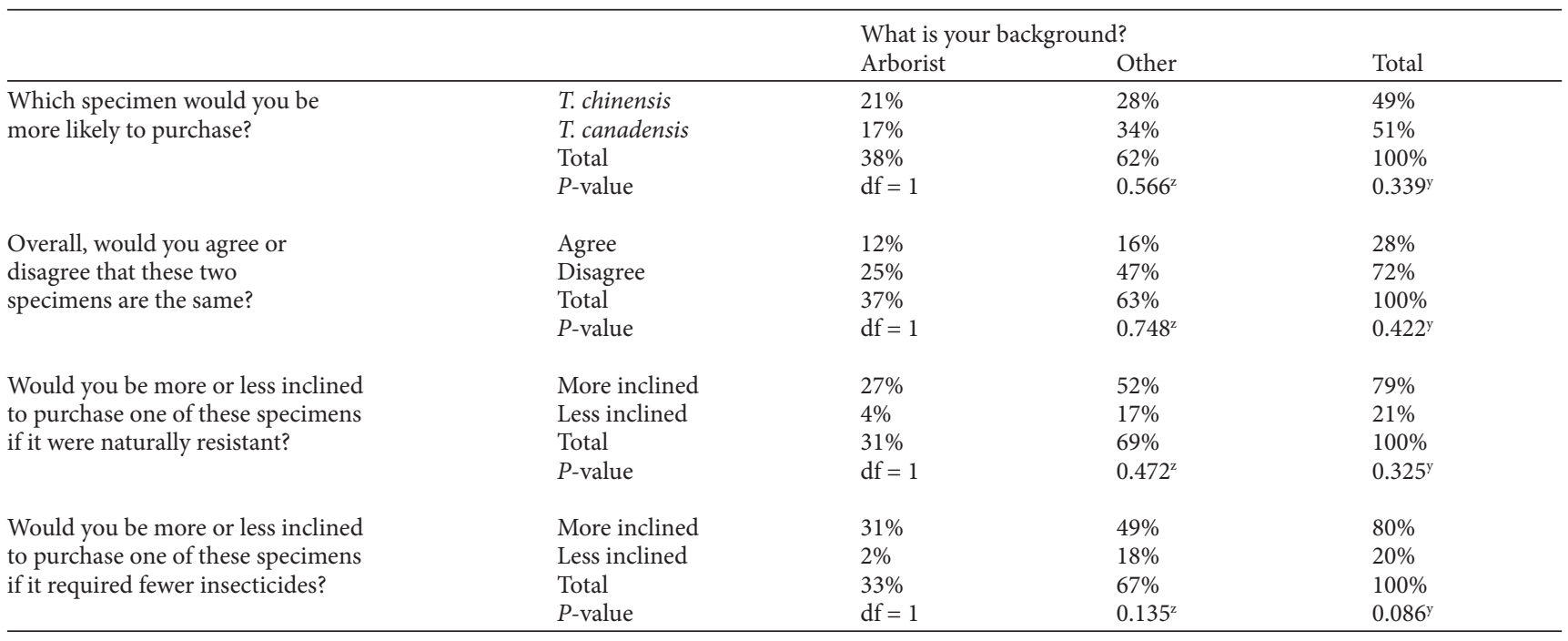

${ }^{2}$ Fisher's Exact Test, exact significance, (2-sided).

${ }^{y}$ Fisher's Exact Test, exact significance, (1-sided).

Table 2. Participant ability to detect specimen difference, versus questions related to plant purchase preferences related to insect plant resistance, and few insecticide requirements.

\begin{tabular}{|c|c|c|c|c|}
\hline & & $\begin{array}{l}\text { Overal } \\
\text { these } t\end{array}$ & $\begin{array}{l}\text { rree or dis } \\
\text { are the san }\end{array}$ & \\
\hline & & Agree & Disagree & Total \\
\hline Would you be more or less inclined to & More inclined & $29 \%$ & $51 \%$ & $80 \%$ \\
\hline purchase one of these specimens & Less inclined & $2 \%$ & $18 \%$ & $20 \%$ \\
\hline if it were naturally resistant? & Total & $31 \%$ & $69 \%$ & $100 \%$ \\
\hline & $P$-value & $\mathrm{df}=1$ & $0.236^{\mathrm{z}}$ & $0.147^{y}$ \\
\hline Would you be more or less inclined to & More inclined & $28 \%$ & $52 \%$ & $80 \%$ \\
\hline purchase one of these specimens if & Less inclined & $2 \%$ & $18 \%$ & $20 \%$ \\
\hline it required fewer insecticides? & Total & $30 \%$ & $70 \%$ & $100 \%$ \\
\hline & $P$-value & $\mathrm{df}=1$ & $0.240^{\mathrm{z}}$ & $0.159^{y}$ \\
\hline
\end{tabular}

${ }^{\mathrm{z}}$ Fisher's Exact Test, exact significance, (2-sided).

${ }^{y}$ Fisher's Exact Test, exact significance, (1-sided). 
research team field notes indicated that participants exhibited interest about the tree's symmetry and fullness (i.e., dense needle cover), its ability to tolerate shade (an important characteristic since so few shade-tolerant evergreen options exist for landscapes), its resistance to other invasive insects and deer herbivory, whether it had the potential to demonstrate invasive tendencies (Rotherham 2005), and how T. chinensis would respond to common maintenance practices like shearing. Furthermore, participants inquired about a timeline relating to the commercial availability of $T$. chinensis. This participant feedback suggests a high level of engagement and genuine interest in T. chinensis.

Since all participants were sampled on the basis of their arboricultural and horticultural experience and knowledge, they likely possessed increased insight into plant selection and more specifically the challenges of establishing and maintaining healthy $T$. canadensis in regions affected by HWA. In addition to contending with HWA, arborists and horticulturalists must consider other variables relative to tree establishment and maintenance in the landscape that may influence Tsuga spp. health and performance. These include soil conditions, light requirements, salt tolerance, pest-resistance, and maintenance schedules that may feature insecticide applications (Harper and Cowles 2013). If the autecologically and aesthetically similar HWA-resistant T. chinensis can be made widely available, then these green-industry professionals will be able to obtain and install an important alternative to the HWAsusceptible T. canadensis in managed landscapes.

A potential limitation of this study may relate to the time of year that it was conducted. At the time of the survey, T. chinensis had already broken bud, with a new flush of growth having already occurred earlier than that of T. canadensis. As observed by one participant, this succulent, new growth may have affected visual characteristics of the plant. Another source of error could include the likelihood that some participants attended past events at this publicly accessible venue, which may have included visiting these study plots. It is possible that some participants knew that $T$. chinensis specimens had been established and successfully growing onsite since 2003.

Future research might include working with larger numbers of participants who could be sam- pled from other geographic regions affected by HWA. If regional Tsuga spp. preferences do in fact exist, a study that incorporates a broader geographical range may detect such differences. One obvious challenge of engaging in a larger-scale study would be locating accessible sites that have well-established T. chinensis-a largely undiscovered plant in the horticultural sector-growing in the vicinity of T. canadensis. Also, due to the limitations in the study's inference space, future work could expand to investigate preferences in the general public and among other horticulture professionals, such as nursery growers and garden-center employees. This strategy may provide additional information that could be used in the marketing and distribution of $T$. chinensis upon commercial availability.

The results are most relevant to the lower Hudson Valley, New York, U.S., area, but indicate that arborists and horticulturists are indeed willing to consider $T$. chinensis as a viable pest-resistant landscape alternative to HWA-susceptible $T$. canadensis. This trend may apply in other locations where $T$. canadensis is found, including other regions of the U.S., as well as internationally.

Acknowledgments. The authors wish to thank the following organizations and individuals for their support: University of Massachusetts Center for Agriculture, Food and the Environment; Brett Butler, Ph.D.; Michael E. Montgomery, Ph.D.; Kathleen Carroll; Christopher Copeland; Victoria Sturner; Cornell University-NYS Integrated Pest Management Program and Cooperative Extension Associations of Putnam, Westchester Counties; Brian Eshenaur; Matt Frye, Ph.D.; Jennifer Stengle; Jerry Giordano; Paul A. Weston, Ph.D.; Ted Kozlowski, the staff at Lasdon Park \& Arboretum and the Westchester County Department of Parks, Recreation, and Conservation.

\section{LITERATURE CITED}

Bentz, S.E., R.J. Griesbach, M.R. Pooler, and A.M. Townsend. 2006. Tsuga chinensis as a source of host resistance to the hemlock wooly adelgid. pp. 24-25. In: K. Gottschalk (Ed.). Proceedings of the 17th Annual Interagency Research Forum on Gypsy Moth and Other Invasive Species. United States Department of Agriculture, Forest Service, Northern Research Station.

Chen T.L., P.F. Hong, Y.C. Lin, and J.C. Huang. 2009. Visual image analysis of Alishan five-wood species in Taiwan. Forest Products Industries 28(1):13-26.

Childs, R.D. 2011. Factsheet: Gypsy moth. University of Massachusetts Extension. Accessed May 2, 2014. <http://extension.umass. edu/landscape/fact-sheets/gypsy-moth>

Del Tredici, P., and A. Kitajima. 2004. Introduction and cultivation of Chinese hemlock (Tsuga chinensis) and its resistance to hemlock woolly adelgid (Adelges tsugae). Journal of Arboriculture 30(5):282-287. 
Dirr, M.A. 2009. Manual of woody landscape plants: Their identification, ornamental characteristics, culture, propagation, and uses, sixth edition. Stipes Publishing L.L.C., Chicago, Illinois, U.S. 1325 pp.

Dreistadt, S.H., D.L. Dahlsten, and G.W. Frankie. 1990. Urban forests and insect ecology: Complex interactions among trees, insects, and times. BioScience 40:192-198.

Dunlap, R.E., and C.E. Beus. 1992. Understanding pubic concerns about pesticides: An empirical examination. Journal of Consumer Affairs 26:418-438.

Evans, A.M. 2008. Infestation by hemlock woolly adelgid of two exotic hemlock species in a New England Forest. Journal of Sustainable Forestry Growth 26:223-240.

Field, A. 2009. Discovering Statistics Using SPSS, third edition. SAGE publications, Ltd., London, England. 690 pp.

Gandhi, K.J.K., and D.A. Herms. 2010. Direct and indirect effects of alien insect herbivores on ecological processes and interactions in forests of eastern North America. Biological Invasions 12:389-405.

Gilden, R.C., K. Huffling, and B. Sattler. 2010. Pesticides and health risks. Journal of Obstetric, Gynecologic \& Neonatal Nursing 39(1):103-110.

Godman, R.M., and K. Lancaster. 1990. Tsuga canadensis (1.) Carr. pp. 604-612. In: R.M. Burns and B.H. Honkala (Eds.). Silvics of North America: Volume 1 Conifers. Agriculture Handbook 654. U.S. Department of Agriculture, Forest Service, Washington, D.C.

Haack, R.A., F. Hérard, J. Sun, and J.J. Turgeon. 2010. Managing Invasive Populations of Asian Longhorned Beetle and Citrus Longhorned Beetle: A Worldwide Perspective. Annual Review of Entomology 55:521-546.

Harper, R.W., and R.S. Cowles. 2013. Susceptibility of Chinese hemlock (Tsuga chinensis) to injury from autumn horticultural oil applications. Arboriculture \& Urban Forestry 39(1):6-10.

Havill, N.P., and M.E. Montgomery. 2008. The role of arboreta in studying the evolution of host resistance to the hemlock woolly adelgid. Arnoldia 65:2-9.

Hoover, B.K., R.K. Bates, J.C. Sellmer, and G.A. Hoover. 2009. Challenging Chinese hemlock (Tsuga chinensis) with hemlock woolly adelgid (Adelges tsugae) ovisacs. Arboriculture \& Urban Forestry 35:1-4.

Ingram, J.B. 2002. Hemlock landscape management. pp. 233-234. In: B. Onken, R. Reardon, and J. Lashomb (Eds.). Proceeding of hemlock woolly adelgid in the eastern United States symposium. Northeastern Area State and Private Forestry, Morgantown, West Virginia, U.S.

ISA (International Society of Arboriculture). 2014. Verify an ISA Certification / Find a Tree Care Service. Accessed January 31, 2014. <www.isa-arbor.com/faca/findArborist.aspx >

Joseph, S.V., S.K. Braman, and J.L. Hanula. 2011. Effects of fertilization of four hemlock species on Adelges tsugae (Hemiptera: Adelgidae) growth and feeding preference of predators. Journal of Economic Entomology 104:288-298.

Kok, L.T., S.M. Salom, M. Beck, R. Mays, B.M. Eisenback, T.J. McAvoy, and T. Dellinger et al. 2013. Biological control of the hemlock woolly adelgid. Virginia Tech, College of Agriculture and Life Sciences, Department of Entomology. Accessed January 15, 2014. <www.ento.vt.edu/projects/kok-loke/Project9.html>
Montgomery, M.E., S.E. Bentz, and R.T. Olsen. 2009. Evaluation of hemlock (Tsuga) species and hybrids for resistance to Adelges tsugae (Hemiptera: Adelgidae) using artificial infestation. Journal of Economic Entomology 102:1247-1254.

Olsen, R.T., and S.E. Bentz. 2010. Breeding novel hemlock hybrids with resistance to hemlock woolly adelgid. In: B. Onken and R. Reardon (Eds.). Proceedings of the Fifth Symposium on Hemlock Woolly Adelgid in the Eastern United States. USDA Forest Health Technology Enterprise Team, Morgantown, West Virginia, U.S.

Onken, B.P., and R.C. Reardon. 2011. An overview and outlook for biological control of the hemlock woolly adelgid. Chapter 22 . Implementation and status of biological control of the hemlock woolly adelgid. USDA Forest Service Bulletin FHTET-2011-04. Morgantown, WV: U.S. Department of Agriculture, Forest Service, Forest Health Technology Enterprise Team.

Peterson, R. 2000. Public perceptions of agricultural biotechnology and pesticides: recent understandings and implications for risk communication. American Entomologist 41:8-16.

Poland, T., and D. McCullough. 2006. Emerald ash borer: Invasion of the urban forest and the threat to North America's ash resource. Journal of Forestry 104:118-124.

Raaijmakers, Q.A.W., A. van Hoof, H. 't Hart, T.F.M.A. Verbogt, and W.A.M. Vollebergh. 2000. Adolescents' midpoint responses on Likert-type Scale Items: Neutral or Missing Values? International Journal of Public Opinion Research 12(2):208-216.

Raupp, M., R. Ahern, B. Onken, R. Reardon, S. Bealmear, J. Doccola, and P. Wolf et al. 2008. Comparing hemlock woolly adelgid and elongate hemlock scale control in ornamental and forest hemlocks. In: B. Onken and R. Reardon (Eds.). Proc. of the Fourth Symposium on Hemlock Woolly Adelgid in the Eastern United States. USDA Forest Health Technology Enterprise Team, Morgantown, West Virginia, U.S.

Ritchie, J., J. Lewis, and G. Elam. 2003. Designing and selecting samples. pp. 77-108. In: Qualitative research practice: A guide for social science students and researchers. SAGE Publications, London, UK.

Rotherham, I.D. 2005. Invasive plants: Ecology, history and perception. Journal of Practical Ecology and Conservation Special Series 4:52-62.

Schlarbaum, S.E., F. Hebard, P.C. Spaine, and J.C. Kamalay. 1998. Three American tragedies: Chestnut blight, butternut canker, and Dutch elm disease. In: K.O. Britton (Ed.). Exotic pests of eastern forests conference proceedings; 1997 April 8-10; Nashville, TN. U.S. Forest Service and Tennessee Exotic Pest Plant Council: 45-54. Accessed May 02, 2014. <www.srs.fs.usda.gov/ pubs/ja/ja_schlarbaum002.htm>

SPSS. 2009. PASW Statistics for Windows, Version 18.0. Chicago: SPSS Inc.

Ward, J.S., M.E. Montgomery, C.A.S.-J. Cheah, B.P. Onken, and R.S. Cowles. 2004. Eastern hemlock forests: Guidelines to minimize the impacts of hemlock woolly adelgid. United States Department of Agriculture Forest Service, Northeastern Area, State \& Private Forestry, Morgantown, West Virginia, U.S.

Weston, P.A., and R.W. Harper. 2009. Potential of Tsuga spp. from western North America and Asia as replacements for eastern hemlock (Tsuga canadensis). Arboriculture \& Urban Forestry 35(1):5-9. 
Jason E.E. Dampier

University of Wisconsin - Extension

Green Lake County, 571 County Rd., A

Green Lake, Wisconsin, 54941, U.S.

Richard W. Harper (corresponding author)

Department of Environmental Conservation

University of Massachusetts, 160 Holdsworth Way

Amherst, Massachusetts 01003-9285, U.S.

rharper@eco.umass.edu

Lora Schwartzberg

102 Wood End Court

Tafton, Pennsylvania, 18464, U.S.

R. Harvey Lemelin

School of Outdoor Recreation, Parks and Recreation

Lakehead University, 955 Oliver Road

Thunder Bay, Ontario, P7B 5E1

Canada
Zusammenfassung. Die gegenwärtige Forschung, welche die Widerstandfähigkeit von Hemlock-Tannen gegenüber der tödlichen, invasiven Wollschildlaus beschreibt, verdeutlicht, dass die Chinesische Hemlock-Tanne (Tsuga chinensis) möglicherweise ein geeigneter widerstandsfähiger Ersatzbaum für den Austausch von Kanadischer Hemlock-Tanne (T. canadensis) ist. Hier werden die Ergebnisse eines in situ Fragebogens und die Beobachtungen von Teilnehmern präsentiert. Das Ziel dieser Studie war, die Erkenntnisse von Arboristen und anderen Hortikulturisten zu sammeln und $\mathrm{zu}$ bewerten und Präferenzen zwischen der Kanadischen und er Chinesischen Hemlock-Tanne zu finden, um herauszufinden, ob die Chinesische Hemlock-Tanne das Potential besitzt, als alternative Pflanze die Kanadische Hemlock-Tanne zu ersetzen. Fünfundfünfzig Teilnehmer inspizierten visuell beide Arten und antworteten auf die Frage, welche Pflanze sie bevorzugt kaufen würden, welches ihre Präferenzen im Licht der potentiellen Widerstandfähigkeit und der Möglichkeit des geringeren Insektizideinsatzes wären. Multiple Kreuztabulierungen zeigten, dass es keine statistische Verbindung (Fisher's Exact Test, $P>0.05$ ) gibt zwischen den Hintergründen der Teilnehmer (z.B. Arboristen versus andere) und Fragen in Verbindung mit allgemeiner Einkaufsbevorzugung und der Einkaufsbevorzugung, wenn eine Art natürliche Abwehrkräfte besitzt oder weniger Insektizide erfordert. Über Dreiviertel der Teilnehmer waren mehr geneigt, eine Art zu kaufen, die eine Widerstandfähigkeit gegenüber einer ernsten Krankheit aufweist. Diese Ergebnisse verdeutlichen, dass die Chinesische HemlockTanne potentiell als eine gegenüber der Wollschildlaus resistente Alternative zur Kanadischen Hemlock-Tanne in der Landschaft dienen kann.

Resumen. La reciente investigación que describe la resistencia de abetos al aldégido lanudo, letal pulgón invasor del Tsuga chinensis, ha sugerido que puede ser reemplazado en el paisaje urbano por el resistente T. canadensis. Aquí se presentan los resultados de la investigación in situ con base en observaciones y cuestionarios. El objetivo del estudio era recoger y evaluar las percepciones de arbolistas y otros horticultores y las preferencias de compra entre los dos tipos de tsugas para evaluar si el T. canadensis tiene potencial para ser aceptado como un reemplazo alternativo paisaje de Tsuga chinensis. Cincuenta y cinco participantes inspeccionaron visualmente ambos especímenes de tsuga y respondieron a las preguntas acerca de cuál de ellos preferirían comprar a la luz del potencial de resistencia a los insectos y la probabilidad de que un menor número de aplicaciones de insecticidas sea requerida. Múltiples tabulaciones cruzadas indicaron que no hubo asociación estadística (prueba exacta de Fisher, $P>0.05$ ) entre los antecedentes de los participantes (es decir, arbolistas frente a otros) y las preguntas relacionadas con la preferencia de compra en general, y la preferencia de compra si una muestra exhibió la resistencia natural de las plagas o requería menos pesticidas. Más de tres cuartas partes de los participantes fueron más propensos a comprar el espécimen que poseía resistencia a una plaga seria. Estos hallazgos sugieren que T. canadensis puede servir potencialmente como una alternativa resistente al aldégido lanudo en el paisaje. 